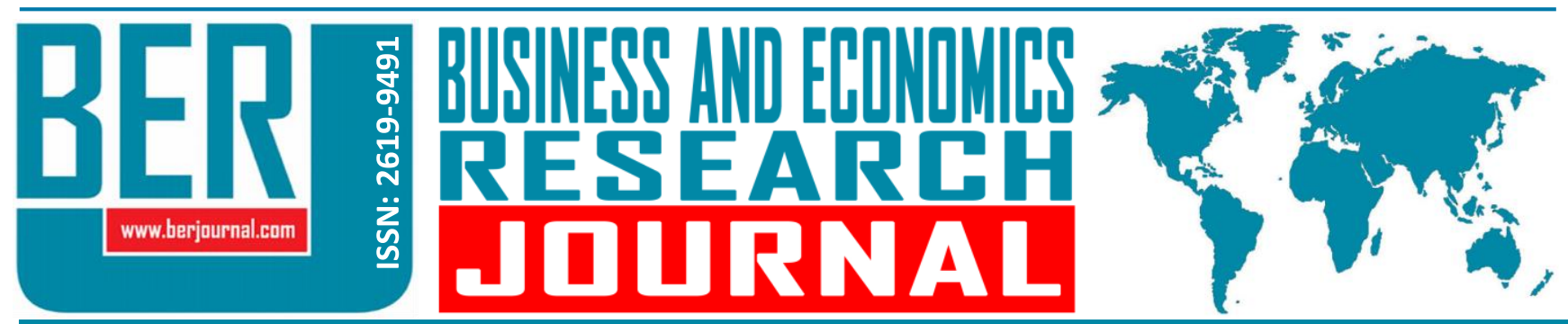

Business and Economics Research Journal Vol. 11, No. 4, 2020, pp. 1147-1162 doi: 10.20409/berj.2020.304

\title{
Temel Benlik Değerlendirmesinin İş Tatminine Etkisinde Psikolojik İyi Oluşun Aracılık Rolü
}

\author{
Muhammet Tortumlua , Abdurrahman Serhan Barutcu ${ }^{\mathrm{b}}$, \\ Tahsin Akcakanat ${ }^{\mathrm{c}}$, Hasan Huseyin Uzunbacak ${ }^{\mathrm{d}}$
}

Öz: Bu çalışmanın amacı, temel benlik değerlendirmesinin iş tatminine etkisinde psikolojik iyi oluşun aracılık rolünü tespit etmektir. Araştırmanın verileri, istanbul'da bulunan bir ilçe belediyesinin çalışanlarından toplanmıştır. Veriler, kolayda örnekleme yöntemi ile toplam 207 beyaz yakalı çalışandan elde edilmiştir. Ölçeklerin geçerliliklerini test etmek için doğrulayıc faktör analizinden yararlanılmıştır. Aracılık rolünü belirlemek için ise bootstrap regresyon analizi kullanılmıştır. Elde edilen bulgulara göre, temel benlik değerlendirmesinin iş tatmini üzerine etkisinde psikolojik iyi oluşun aracılık rolü oynadığı saptanmıştır. Ayrıca çalışmada, temel benlik değerlendirmesi, iş tatmini ve psikolojik iyi oluş değişkenleri arasında anlamlı ve pozitif yönlü etkiler tespit edilmiştir. Bu doğrultuda tespit edilen bulgular akademik yazın çerçevesinde tartışılmış ve önerilerde bulunulmuştur.

\section{The Mediating Role of Psychological Well-Being in the Effect of Core Self-Evaluation on Job Satisfaction}

Abstract: The aim of this study is to determine the mediating role of psychological wellbeing in the effect of core self-evaluation on job satisfaction. The data of the research were collected from the employees of a district municipality in istanbul. The data were obtained from a total of 207 white-collar employees with a convenience sampling method. Confirmatory factor analysis was used to test the validity of the scales. Bootstrap regression analysis was used to determine the mediating role. According to the obtained findings, it was found that psychological well-being played a partial mediating role in the effect of core self- evaluation and job satisfaction on each other. In addition, significant and positive effects were found between core self- evaluation, job satisfaction, and psychological well-being variables. Findings determined in this direction were discussed within the framework of academic literature and various suggestions were made.

\begin{abstract}
Anahtar Sözcükler: Temel Benlik Değerlendirmesi, İş Tatmini, Psikolojik İyi Oluş, Öz Değerlendirme Teorisi, Aracılık Rolü
\end{abstract}

JEL: D23, D73, M12

$\begin{array}{ll}\text { Geliş } & : 22 \text { Haziran } 2020 \\ \text { Düzeltme } & : 28 \text { Ağustos } 2020 \\ \text { Kabul } & : \text { 07 Ekim } 2020 \\ \text { Tür } & : \text { Araştırma }\end{array}$

Keywords: Core Selfevaluation, Job Satisfaction, Psychological Well-Being, Self-evaluation Theory, Mediating Role

JEL: D23, D73, M12

Received : 22 June 2020

Revised : 28 August 2020

Accepted : 07 October 2020

Type : Research

a Lecturer, Burdur Mehmet Akif Ersoy Univesity, Tefenni Vocational School, Department of Management and Organization, Burdur, Turkiye, mtortumlu@mehmetakif.edu.tr (ORCID ID: 0000-0002- 7245-1017)

b PhD. Student, Suleyman Demirel Univesity, Faculty of Economics and Administrative Sciences, Department of Management and Organization, Isparta, Turkiye, serhanbarutcu2009@hotmail.com (ORCID ID: 0000-0003-3859-8653)

Assoc. Prof. PhD., Suleyman Demirel Univesity, Faculty of Economics and Administrative Sciences, Department of Management and Organization, Isparta, Turkiye, tahsinakcakanat@sdu.edu.tr (ORCID ID: 0000-0001-9414-6868)

d Assoc. Prof., PhD., Suleyman Demirel Univesity, Faculty of Economics and Administrative Sciences, Department of Management and Organization, Isparta, Turkiye, hasanuzunbacak@sdu.edu.tr (ORCID ID: 0000-0002-3297-1659) 


\section{Giriş}

Insanlar, karakterleri, kişilikleri ve hayattan beklentileri ile farklı özelliklere sahiptirler. Örgütler ise davranış, tutum ve yaklaşımları ile her biri farklı özelliğe sahip olan iş görenleri, insan kaynakları politikaları ile uyumlu hale getirerek amaçlarına ulaşma eğilimlerindedirler. Bu amaçlara ulaşmanın temel etkenlerinden biri de iş görenlerin işe yönelik davranış, tutum ve yaklaşımlarının incelenmesidir. Bu inceleme alanlarından birisi de temel benlik değerlendirmesi (TBD) kavramıdır. TBD, Judge vd. (1997) tarafından örgütsel davranış yazınına kazandırımıştır. TBD, bireyin değerliliği, etkinliği ve kabiliyeti hakkında kendini içsel ve dışsal değerlendirmesidir. TBD ile ilgili yapılan ilk çalışmada, TBD’nin iş tatmini ve çalışan performansını yordadığı tespit edilmiştir (Judge vd., 2003). Bu bulgu ve araştırmalar, işgörenlerin kendilerini olumlu anlamda değerlendirmelerinin, icra ettikleri işten tatmin olmalarında ve performanslarının artışında etkili olduğunu göstermektedir. Bir başka ifadeyle, çalışanların kendilerini olumsuz anlamda değerlendirmeleri de işten aldıkları doyumu olumsuz etkilediği ve performanslarının düşmesine yol açtığı anlaşılmaktadır. Bu bulgulara rağmen örgütler, arzu edilen hedeflere ve sonuçlara ulaşmakta güçlük çekmektedirler. Bu durum, örgütlerin çalışanları üzerinde dikkatle odaklanması gereken iletişim, çalışan psikolojisi, çalışan memnuniyeti gibi bazı olguların göz ardı edildiğinin göstergesidir. Nitekim iletişim, ücret, terfi, ödüller, iş arkadaşları gibi unsurların iş tatminine doğrudan etkisi olduğu ortaya konulmuştur (Ergeneli ve Yiğit, 2001).

İs tatmini bireyin işten aldığı doyumu ifade etmektedir. İşinden yeterli doyumu almayan çalışanlar, olumsuz duygular yaşayarak, işten uzaklaşma, işi terk etme, sürekli işten yakınma ve umutsuzluk gibi belirtiler gösterir (Izgar, 2008). Tüm örgütler için mutluluk ve iş doyumu olguları kritik bir öneme sahiptir. Çünkü daha mutlu olan çalışanların işten daha fazla doyum aldıkları tespit edilmiştir (Tekirgöl, 2011; Işık vd., 2017). İ̧ görenlerin iş tatmin seviyeleri ve iyi oluş hallerinin, örgüt içi faaliyetlerini doğrudan etkileyen faktörlerden olduğu düşünülmektedir. Nitekim öz benlik algısı yüksek olan bireylerin işlerinden daha fazla tatmin oldukları ifade edilmiştir (Erez ve Judge, 2001). Aristoteles'in temelini oluşturduğu Etkinlik Kuramı'nda, bireylerin amaçlarına ulaşma, hedeflerini gerçekleştirme aşamalarında yapmış oldukları etkinlikler ile psikolojik iyi oluşa ulaşabileceği iddia edilmiştir. Özellikle zevk alarak yapılan etkinliklerin kişinin iyi oluş seviyesini yükselteceği ileri sürülmüştür. Bireyin yaptığı işten yeterli doyum alabilmesi ve iyi hissedebilmesi için işinden memnun olması ve işini sevmesi gerekliliği ortaya çıkmaktadır. Nitekim bireyin öz değerlendirmesinin iyi düzeyde olması, kendisini daha iyi tanımasına ve işten doyum almasında kritik bir öneme sahip olduğu düşünülmektedir.

Kamu yönetiminin en güçlü yerel dinamiği olan belediyeler, hizmet sektörünün lokomotiflerinden biridir. Fen işleri, zabıta hizmetleri, ruhsat ve denetim işlemleri, imar ve şehircilik hizmetleri, destek hizmetleri, kültür ve sanat hizmetleri ve temizlik işleri gibi kritik hizmet ağında görev yapan çalışanların iş doyumları ve psikolojik iyi oluş seviyelerinin, hizmet kalitesine doğrudan etki yapacağı düşünülmüştür. Belediye bir taraftan hizmetleri sunarken, diğer taraftan çalışanları düşünmek durumundadır. Bu açıdan bakıldığında çalışanlar hem hizmet sunan hem hizmet alan taraftır. Çalışanların işten yeterli doyum almaması performanslarının azalmasına etki yapacak (Türkoğlu ve Yurdakul, 2017), dolayısıyla belediyenin amaç ve hedeflerini gerçekleştirmesi zorlaşacaktır. Bu sebeple, belediye çalışanları araştırmanın örneklemi olarak belirlenmiştir.

Bu çalışmanın temel amacı; TBD’nin iş tatminine etkisinde psikolojik iyi oluşun aracılık rolünü incelemektir. Nitekim değişkenlerle ilgili yazında birçok araştırma yapılmış, ilişkiler ortaya konulmuştur. Fakat psikolojik iyi oluşun aracılık rolüne yönelik herhangi bir çalışmaya rastlanmamıştır. Bu kapsamda yazına katkıda bulunacağı değerlendirilen çalışmanın araştırma sorusu, “TBD'nin iş tatminine etkisinde psikolojik iyi oluşun aracılık rolü var mıdır?" şeklinde belirlenmiştir. Çalışmada bu sorunun cevabı nicel analizle ortaya çıkarılmaya çalışılmıştır. 


\section{Kavramsal Çerçeve ve Hipotezler}

\subsection{Temel Benlik Değerlendirmesi}

TBD; Judge vd. (1997) tarafından, kişinin önce kendine, sonra dünya ve başkalarına ilişkin temel değerlendirmeleri olarak tanımlamıştır. TBD, bireyin samimiyet ve dürüstlük esasını temel alarak değerliliği, etkinliği ve kabiliyeti hakkında kendini içsel ve dışsal değerlendirmesi olarak tanımlanabilir. Judge ve arkadaşları yapmış oldukları çalışmalar neticesinde TBD'nin dört alt boyutunu birbiri içinde eriterek tek boyut haline getirmişler ve buna "Temel Benlik Değerlendirmesi Envanteri" adını vermişlerdir. Bu envanteri kullanarak bireylerin kişilik özelliklerinin ölçümünde kullanılabileceğini dile getirmişlerdir (Judge vd., 1997).

TBD; özsaygı (self-esteem), öz yeterlilik (generalized self-efficacy), duygusal denge (neuroticism) ve kontrol odağı (locus of control) olmak üzere dört alt faktörden oluşmaktadır. Özsaygı; bireyin kendini genel değerlendirmesi çerçevesinde değerli, saygın ve başarılı olup olmadığı sorgulamasının sonucu ortaya çıkan neticedir. Özsaygı kişinin kendini genel değerlendirmesidir. Öz saygısı yüksek olan bireylerin öznel iyi oluş ve iyimserlik eğilimlerinin de olumlu anlamda artış gösterdiği tespit edilmiştir (Eryılmaz ve Atak, 2011). Öz yeterlilik; bireyin belli bir durumda kendisinden beklediği gibi süreci yönetmesine katkı yapacak yeteneklerine olan inancıdır (Bandura, 1995). Yani öz yeterlilik, kişinin sosyal ya da mesleki anlamda karşısına çıkacak problemleri çözüp çözemeyeceği konusunda kendisine olan inancıdır. Duygusal denge, kişinin kendini genel anlamda depresyonda hissetmesi, kendine güvenmemesi ve yüksek düzeyde kaygı yaşama durumudur (Watson, 2000). Duygusal denge seviyesi yüksek bireyler yaşadıkları belirsizlik karşısında diğer insanlara nazaran daha olumsuz duygular içerisine girmektedirler (Schneider, 2004). Duygusal denge düzeyi düşük olan bireyler ise belirsizlik gibi durumlar karşısında daha rahat ve sakin kalabilmektedirler (Nübold vd., 2013). Kontrol odağı; kişilerin olaylar karşısında gösterdikleri davranışlar neticesinde ortaya çıkabilecek sonuçlar ile ilgili beklentileridir (Angelova, 2016). Kontrol odağı kavramı, iç kontrol odağı ve dış kontrol odağı olmak üzere iki boyutta incelenmiştir. İç kontrol odağı, kişinin çevresinde meydana gelen olayların kendi gerçekleştirdiği davranışlar sonucu ortaya çıktığına inanması durumudur. Dış kontrol odağı ise bireyin çevresinde meydana gelen olayların kaynaklarının kader, şans ya da olağanüstü bazı güçlerin olduğuna inanma halidir (Çırakoğlu ve Tezer, 2010).

\section{2. İş Tatmini}

İ̧ tatmini kavramının ilk kullanımı 1935 yılında Hoppock'un “iş Tatmini” isimli çalışması ile olmuştur (Akdemir ve Açan, 2017). Konuyla ilgili çok fazla çalışma olmasına rağmen iş tatmini kavramının kesin sınırları netleştirilememiştir. Bunun nedeni ise iş tatmininin birçok faktörden etkilenme özelliğidir. Bununla birlikte, iş tatmini örgütsel hayat üzerinde önemli etkilere sahip olduğundan üzerinde çok durulan bir konu haline gelmiştir (Arslan ve Demir, 2017). Bu kadar önemli olan tatmin kavramı; "istenen bir şeyin gerçekleşmesini sağlama, gönül doygunluğuna erme, doyum" olarak tanımlanmıştır (TDK, 2020). İ̧̧ tatmini ise birçok araştırmacı tarafından farklı şekillerde tanımlanmıştır. Luthans (2011)'a göre iş tatmini, çalışanların işlerinin, kendileri için önemli olarak gördükleri şeyleri ne kadar iyi sağladığına dair algılarının bir sonucudur. Robbins ve Judge (2019), işin özelliklerinin değerlendirilmesi sonucu oluşan iş hakkındaki olumlu his olarak tanımlamışlardır.

İş tatmini genel olarak içsel ve dışsal tatmin olmak üzere ikiye ayrılmaktadır. Bu sınıflandırmada içsel faktörler Herzberg'in güdüleyici faktörlerini yani başarı, tanınma, takdir edilme, işin kendisi, işin sorumluluğu, yükselme gibi kavramları; dışsal faktörler ise hijyen faktörleri yani işletme politikası, denetim şekli, yönetici ve astlarla ilişkiler, iş yerine ilişkin çalışma koşullarını temsil etmektedir (Akdemir ve Açan, 2017).

Literatürde iş tatminini etkileyen faktörler farklı boyutlar altında sınıflandırılmaktadır. Bu faktörlerden birincisi işin kendisidir. İşin kendisi; işin bireye yüklediği görevler, sağladığı fırsatlar ve sorumluluk üstlenme şansıdır. Çalışanın önemli ve anlamlı bir iş yaptığını düşünmesi ve yaptığı işten mutlu olması iş tatminini arttırmaktadır. İkincisi ücrettir. Ücret olarak alınan miktar örgütteki diğerlerine göre eşit ve uyumlu ise kişiyi motive eder. Çalışanın aldığı ücret yeterli ise tatmin oluşacakken, yetersizse tatminsizliğe yol açmaktadır. Üçüncüsü terfi imkânlarıdır. Çalışanlara terfi imkânı sunulduğu takdirde iş tatminleri artmaktadır. Dördüncüsü 
gözetim ve denetimdir. Gözetim ve denetim, çalışanların üstlerinden aldığı teknik yardım ve davranış desteğidir. Çalışanların üstleriyle olan ilişkilerinin iyi olması orta düzeyde bir tatmin kaynağıdır. Beşincisi ise iş arkadaşları olup; çalıştığı iş arkadaşlarının sağladığı sosyal destek ve mesleki bilgi desteğidir (Akdemir ve Açan, 2017). Iş̧ arkadaşlarının çalışana sağladığı destek ve gösterdiği iş birliği, iş tatminini önemli oranda etkilemektedir (Erdirençelebi ve Ertürk, 2018).

Görüldüğü gibi iş tatmini birçok araştırmacı tarafından çeşitli şekillerde tanımlanmış ve sınıflandırılmıştır. Bu tanımlamalardan çıkarılabilecek sonuçlar; iş tatmini, çalışanların işlerinden duyduğu memnuniyet ve hazzı gösterir, çalışanların işleriyle ilgili neler hissettiğini ortaya koyar. İ̧ tatmini gözlenemez olup, içsel bir süreci ifade ettiğinden ancak davranışlardan anlaşılabilir. İş tatmini, çalışanın elde etmek istediğini elde ettiğinde ya da beklentilerinin ötesinde kazanımları elde ettiğinde ortaya çıkmaktadır. Ayrıca birçok ve birbiriyle bağlı tutumları kapsamaktadır (Temel Eğinli, 2009).

\subsection{Psikolojik İyi Oluş}

Psikolojik iyi oluş, ilk olarak 1969'da Bradburn tarafından "The Structure of Psychological Well-Being" adlı eserde kullanılmıştır. Bradburn, psikolojik iyi olma durumunu, olumlu duyguların olumsuz duygulara baskın olması ile açıklamıştır (Karacaoğlu ve Köktaş, 2016). Psikolojik iyi oluş kavramını günümüzdeki anlamıyla ilk ortaya atan Ryff olmuştur (Tatlıoğlu, 2015). Ryff, psikolojik iyi oluşu altı farklı bileşenle incelemiştir. Bu bileşenleri de öz kabullenme (self acceptance), diğer kişilerle olumlu ilişkiler (positive relations with others), özerklik (autonomy), çevresel hâkimiyet (environmental mastery), yaşam amacı (purpose in life) ve kişisel gelişim (personal growth) olarak belirlemiştir (Ryff, 1989; Ryff, 1995). Öz kabullenme, bireyin geçmiş yaşantısını ve kendisini pozitif olarak görebilmesi olarak tanımlanmaktadır. Yaşam amacı, yaşamda bir maksat ve yöne sahip olabilme olarak nitelendirilmektedir. Kişisel gelişim, bireyin sürekli bir değişim ve gelişim içerisinde olduğuna inanması, sürekli gelişime önem vermesi, potansiyel becerilerini kullanabilmesi ve yeni deneyimlere açık olmasıdır. Diğer kişilerle olumlu ilişkiler, bireyin diğer bireylerle nitelikli, güvene dayalı ve sağlıklı sosyal ilişkiler kurması olarak tanımlanmaktadır. Çevresel hâkimiyet, bireyin çevresini ve yaşamını yönetebilme kabiliyetine sahip olması anlamını taşımaktadır. Özerklik ise bireyin kararlarını almasında ve davranışlarını belirlemesinde özgür olabilmesi anlamına gelir (Ryff, 1995). Psikolojik iyi oluşun altı farklı bileşeni dikkat alınarak tek boyut halinde sekiz maddeden oluşun bir ölçek geliştirilmiştir (Diener vd., 2010).

Bir kişinin psikolojik iyi oluş halinden bahsedebilmek için onun diğer kişilerle yakın ilişkilerde bulunmaktan kaçınmayan, samimi, empati kurabilen, başkalarına yardım eden, düşünce ve davranışlarını kendi doğrularına göre belirleyen, denetimini kendi yapan, ruh haline göre çevre seçen ya da oluşturan, kişisel potansiyelini geliştiren, yaşamı ve amacını kavrayabilen, davranış ve duygularının farkında ve onlara karşı olumlu tavır sergileyen biri olması gerekmektedir (Ertürk vd., 2016). Psikolojik olarak iyi oluş halinde olan kişilerin, bedensel ve zihinsel sağlıklarının, iş ve özel hayat doyumlarının, kendilerine güven, motivasyon ve olumlu düşünme kabiliyetlerinin daha yüksek olması beklenmektedir (Keleş, 2017).

Psikolojik iyi oluş kavramı, kişinin kendisini ve yaşamını nasıl değerlendirdiği ve nitelediği ile ilgili bilgiler vermektedir (Telef vd., 2013). Psikolojik iyi oluş, yaşamın varoluşsal zorlukları karşısında algılanan gelişmeleri (anlamlı hedeflere ulaşmak, kişisel olarak büyümek ve gelişmek, diğer kişilerle kaliteli bağlar kurmak gibi) inceler (Keyes, vd., 2002). Psikolojik iyi oluş bakış açısına göre, insanın iyi olma hali, iyi hissetmekten ziyade daha iyi yaşama ve daha iyi şeyler yapma olarak belirtilmiştir (Telef vd., 2013). Yapılan çalışmalar psikolojik iyi oluşla ilgili olarak önemli örgütsel çıktılar vermektedir (Oruç, 2019). Bu çalışmalarda, çalışanların psikolojik iyi oluş halinin iş tatmini, işten ayrılma niyeti, işgücü devir oranı, örgütsel bağlılık, motivasyon ve performans gibi önemli değişkenler üzerindeki rolüne odaklanılmaktadır (Özdemir, 2016). Psikolojik iyi oluşun çalışanların bedensel sağlıklarını (Wright vd., 2009), iş kaynaklarını arttırarak işle bütünleşmelerini (Aiello ve Tesi, 2017) ve performanslarını (Akdoğan ve Polatçı, 2013) arttırdığını, bunun yanında ise işten ayrıma niyetlerini azalttığını (Wright ve Bonett, 2007) gösteren çalışmalar da bulunmaktadır. Ayrıca psikolojik olarak iyi olan çalışanların, örgütsel bağlılık ve örgütsel adanma düzeylerinin yüksek olduğu belirlenmiştir (Ertürk vd., 2016). Sonuç olarak çalışanların işyerinde psikolojik iyi oluşlarını sağlayabilmeleri için geliştirebilecekleri yolların incelenmesi örgütler için büyük önem taşımaktadır (Oruç, 2019). 


\subsection{Değişkenler Arası İlişkiler}

\subsubsection{Temel Benlik Değerlendirmesi ile İş Tatmini İlişkisi}

TBD kavramının literatüre kazandırılması Öz Değerlendirme Teorisi'nden yola çıkarak sağlanmıştır. Öz Değerlendirme Teorisi'nin ilk ortaya çıkışı Edith Packer'ın (1985) “öz değerlendirme” kavramını literatüre kazandırarak tanımlaması ile gerçekleşmiştir. Teori, kişinin bilinçaltının en alt seviyelerinde sakladığı değerlendirmeler olduğunu ileri sürmektedir. Teorinin kurucusu Packer'a göre, benlik olgusu yaşamın benlik, dünya ve diğer insanlar olmak üzere üç temel alan ile ilişkilidir. Illişkisel Kimlik Teorisi ise, işgörenlerin kişilik özelliklerinin işe yönelik tutumlarını ve iş yapma şekillerini değiştirebileceğini öne sürmüştür (Shapiro, 2010). Bu teorik altyapı ile TBD’nin örgütsel davranış bağlamında iş tatmini kavramıyla ilişkilendirilmesi ilk olarak Judge vd. tarafından yapılmıştır. Judge vd. (1997) TBD ile iş tatmini arasında pozitif yönlü bir ilişki olduğunu ve TBD'nin iş tatminini pozitif yordadığını saptamışlardır. Bir başka çalışmada TBD'nin iş tatmini ve iş performansı ile anlamlı ölçüde ilişkili olduğu; TBD’nin iş tatminini, iş performansından daha çok yordadığı sonucuna ulaşılmıştır (Gürbüz vd., 2010). Yine bir diğer çalışmada TBD'nin iş tatmine etkisinde iş özelliklerinin aracılık ettiği bulunmuştur (Judge, 2001). TBD'nin boyutlarından olan öz yeterlilik değişkeni ile iş tatmini ve iyi oluş kavramlarının ilişkisini Bandura'nın Sosyal Bilişsel Kuramı içerisinde ortaya çıkardığı öz yeterlilik kuramı açıklamaktadır. Öz Yeterlilik Kuramı, Bandura tarafından Sosyal Bilişsel Teori kapsamı içerisinde tanımlanmıştır. Kuram, kişinin neleri başarabileceği konusundaki algısına dikkat çekmiştir. Öz yeterlilik düzeyi yüksek olan bireyler işleri fırsat olarak görmektedirler (Bandura, 1995). Bunun yanında, TBD’nin alt boyutlarından olan özsaygı değişkeni ile iş tatmini arasındaki ilişki de Korman'ın Öz Tutarlılık Teorisi ile açıklanabilmektedir. Öz Tutarlılık Teorisi (Korman, 1970), bireylerin kendi imajları ile tutarlı bir şekilde davranmaya motive olduklarını varsaymaktadır. Bu nedenle, teori, yüksek özsaygı düzeyine sahip bireylerin olumlu benlik imajlarını korumak için etkili bir şekilde performans göstereceklerini öngörmektedir (Judge ve Bono, 2001). Korman (1970) özsaygıyı, kişinin kendisini yeterli ve ihtiyaçları tatmin olmuş bir birey olarak görmesi şeklinde açıklamaktadır (akt. Çakmak Otluoğlu, 2015). Teoriye göre, özsaygı düzeyi yüksek olan bireylerin çıkarlarıyla tutarlı meslekleri seçeceği, bunun da daha fazla tatminine yol açacağı düşünülmektedir. TBD'nin boyutlarından kontrol odağının iş tatmini ile pozitif yönde ilişkili olduğu tespit edilmiştir. (Chen ve Silverthorne, 2008; Ajibola, 2020). Yine TBD'nin bir diğer boyutu olan duygusal dengenin de iş tatmini ile negatif ilişkisi birçok çalışmada ifade edilmiştir (Hlatywayo vd., 2013; Rukh vd., 2020). Buradan hareketle $H_{1}$ hipotezi geliştirilmiştir.

\section{$H_{1}$ : TBD'nin iş tatmini üzerinde anlamlı bir etkisi vardır.}

\subsubsection{Temel Benlik Değerlendirmesi ile Psikolojik İyi Oluş ilişkisi}

Bireyler iş hayatları süresince kendileri ve çalışma arkadaşları ve çevresiyle ilgili birçok içsel değerlendirmelerde bulmaktadırlar. Bu doğrultuda birey dış dünya ile ilgili yapmış olduğu olumsuz değerlendirmelerin iş yaşamlarındaki tatmin seviyelerinin olumsuz etkileneceği çeşitli araştırmalarla kanıtlanmıştır. Nitekim Psikolojik iyi oluş kavramı özellikle TBD boyutlarından özsaygı ve öz yeterlik değişkenleri ile ilişkilendirilmiş ve bu kavramların birbiriyle pozitif yönde etkileştiği, özsaygı ve öz yeterliliğin iyi oluşu pozitif yönde yordadığı tespit edilmiştir (Doğan ve Eryılmaz, 2013). Bandura'nın Sosyal Bilişsel Kuramı, bireylerin başarabileceklerine inandıkları işlere girmeye kolayca ikna olabildikleri, başaramayacağı işlere eğilim göstermediklerini vurgulamıştır (Bandura, 1995). Bireyin başarmakta zorlanacağı işleri gerçekleştirmesi, kendisi ile ilgili yeterlilik algısını artırarak sorun çözme yeteneklerini geliştirmesine katkı yapar. Bu teoriye göre bireyin başkalarının yapabildiği fakat kendisinin yapma konusunda tam olarak yeterli görmediği durumlarda fiziksel durumu, psikolojik durumu, iyi oluş hali veya kaygı, stres, yorgunluk düzeyleri önemli bir etkiye sahiptir.

Özsaygısı yüksek olan bireylerin mutluluk seviyelerinin de yüksek olduğu tespit edilmiştir (Baumeister vd., 2003). Yapılan bir diğer çalışmada ise iyi oluş yani mutluluğun özsaygı ve öz yeterlik ile ilişkisinin anlamlı ve pozitif yönde olduğu fakat farklı kavramlar olduğuna dikkat çekilmiştir (Lyubomirsky vd., 2006). Yapılan bir çalışmada TBD boyutlarından olan kontrol odağının mutluluk ile ilişkili olduğu saptanmıştır (Ramezani ve 
Gholtash, 2015). Yine bir başka yapılan çalışmada mutluluğun iç kontrol odağı ile ilişkili olduğu tespit edilmiştir (Pannells ve Claxton, 2008). Buradan hareketle $H_{2}$ hipotezi geliştirilmiştir.

\section{$H_{2}$ : TBD’nin psikolojik iyi oluş üzerinde anlamlı bir etkisi vardır.}

\subsection{3. İş Tatmini ile Psikolojik İyi Oluş Ilişkisi ve Psikolojik İyi Oluşun Aracılık Rolü}

Mutluluk kuramlarından Ereksel Kuramlar, iyi oluşun, bireylerin ihtiyaçlarının doyurulması ile ortaya çıkacağını ileri sürmüş, hedeflenen amaçlara ulaşılması sonucunda ortaya çıkabileceğini vurgulamıştır (Yetim, 2001). Aristotales'in temelini attığı Etkinlik Kuramı ise mutluluğun, kişinin erdemli etkinliklerinden kaynağını aldığını savunmuş, mutluluğun son durumda yaşanılan bir duygu durumu olmadığını ifade etmiştir (Büyükdeveci, 1993). Etkinlik Kuramı mutluluğun aslında yaşamsal süreç içerisinde yaşanılan bir duygu durumu olduğunu ifade etmektedir. Etkinlik Kuramları dikkate alındığında iyi oluş halinin aslında bir sonuç olmadığı, aksine yaşamın içerisinde bir süreçte gerçekleştiği; bu yönüyle bireylerin tutumlarını etkileyebileceği düşünülmüştür. Genişletme ve İnşa Etme Teorisi, bireylerin iyi oluş gibi olumlu duygularının anlık düşünce ve eylem repertuarlarını genişlettiğini, olumsuz duygu durumlarının ise tam tersi etki yaparak düşünce ve eylemleri daralttığını ileri sürmektedir (Fredrickson, 2004). Kuram, olumlu duyguların yeni bilgiler edinmeyi ve yaratıcı düşünceyi geliştirildiğini vurgulamıştır. Psikolojik açıdan iyi olmayan bireylerin işine ve çalışma arkadaşlarına yönelik daha olumsuz duygular beslediği vurgulanmıştır (Wright vd., 2007). Psikolojik iyi oluş düzeyleri yüksek olan bireylerin ise işlerinden daha memnun oldukları ve bu vesileyle, kendilerini işe yönelik daha kolay geliştirebildikleri ifade edilmiştir (Fredrickson, 2004). Bu kapsamda yapılan bir çalışmada psikolojik iyi oluşun iş performansı ile iş tatmini arasındaki ilişkide aracılık rolü tespit edilmiştir (Wright vd., 2007).

İyi oluş, neşe, tatmin, refah ve yaşam memnuniyetinin bir bileşeni olarak tanımlanmaktadır (Lyubomirsky, 2007). İyi oluş seviyesi yüksek olan bireylerde, olumsuz duygularının düşük olduğu, sosyal yaşamlarında ve iş yaşamlarında yaşam memnuniyetlerinin ve tatmin seviyelerinin yüksek olduğu söylenebilir. Bu kişilerin sadece kendilerini iyi hissetmekle kalmayıp çevreleriyle iyi ilişkiler kurduğu, yaratıcılık seviyelerinin yüksek olduğu ve iş yaşamlarında başarılı oldukları tespit edilmiştir (Lyubomirsky vd., 2005). Bireylerin mutluluklarının iş doyumları üzerinde olumlu ya da olumsuz bir etkiye sahip olması kaçınılmazdır (Bakan ve Büyükmeşe, 2004). İş tatmini ile iyi oluş arasında pozitif bir ilişki olduğu birçok araştırma neticesinde ortaya konulmuştur (Micholos ve Orlando, 2006; Curhan vd., 2009; Bowling vd., 2010). Bu kapsamda bireylerin duygu durumlarının, iş hayatı boyunca oldukça önemli bir yere sahip olduğu belirtilmiştir (Gürbüz ve Yüksel, 2008). İyi oluşun iş tatminine etkisini araştıran bir çalışmada, çalışan kadınların iyi oluş düzeylerinin artması ile işten aldıkları doyumun arttığı tespit edilmiştir (ışık vd., 2017). Psikolojik iyi oluş, bireylerin zihinsel iyilik halini koruyarak motivasyonu, performansı ve örgütsel bağlılı̆ı artırmaktadır (Awang vd., 2015). Bu bulgu ile psikolojik iyi oluşun bireylerin çalışma hayatlarına önemli ölçüde etki yaptığı anlaşılabilmektedir. Nitekim bireylerin iyi oluş halleri üzerine araştırmalar yapan Shawn Achor (2011) mutluluğun formülü olarak görülen " Daha çok çalışırsan daha başarılı olursun, daha başarılı olursan daha çok mutlu olursun" denkleminin yanlış olduğunu ifade edip, bu formülün tersine çevrilmesi gerektiğini vurgulamış, bunu da "Mutluluk avantajı" olarak adlandırmıştır. Yapılan araştırımalar incelendiğinde, hem psikolojik iyi oluşun iş tatmine pozitif etkisi (Illies vd., 2006; Curhan vd., 2009) hem de iş tatmininin psikolojik iyi oluşa pozitif yönlü etkisi tespit edilmiştir (Tekirgöl, 2011; Işık vd., 2017). Yapılan bir başka araştırma da iyi oluş ile iş tatmini ilişkisinin aslında karşılıklı bir ilişki olduğunu tespit etmiş, iyi oluşun iş tatmine etkisinin, iş tatmininin iyi oluş üzerindeki etkisinden daha güçlü olduğu vurgulanmıştır (Bowling vd., 2010). Buradan hareketle $\mathrm{H}_{3}$ ve $\mathrm{H}_{4}$ hipotezleri geliştirilmiştir.

\section{$\boldsymbol{H}_{3:}$ Psikolojik iyi oluşun iş tatmini üzerinde anlamlı bir etkisi vardır. \\ $\boldsymbol{H}_{4:}$ TBD’nin iş tatmini üzerindeki etkisinde psikolojik iyi oluşun aracılık rolü vardır.}

\section{Yöntem}

Çalışanların TBD düzeylerinin iş tatmini seviyeleri üzerindeki etkisi ile bu etkide psikolojik iyi oluşun aracılık rolü olduğu varsayımına ilişkin olarak oluşturulan teorik yapının test edilmesi amacını taşıyan bu 
araştırmanın modeli Şekil 1'de görülmektedir. TBD’nin iş tatmini üzerine etkisinde, psikolojik iyi oluşun aracılık rolünün tespiti, Process makrosu kullanılarak bootstrap regresyon analizi ile gerçekleştirilmiştir.

Şekil 1. Araştırmanın Modeli

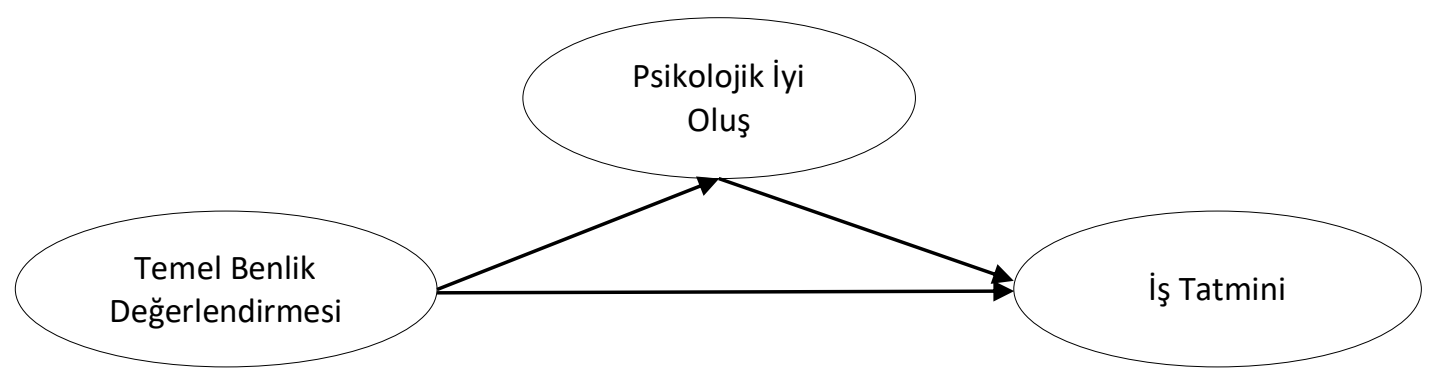

\section{1. Örneklem}

Araştırmanın örneklemini İstanbul'da bir ilçe belediyesinde görevli 207 beyaz yakalı çalışan oluşturmaktadır. Araştırmanın verileri 2019 yılı Kasım ayı içerisinde toplanmıştır. Araştırma, belediye organizasyonu içerisindeki fen işleri, halkla ilişkiler, imar ve şehircilik, ruhsat ve denetim, zabıta ve insan kaynakları müdürlüklerinde görev alan ofis çalışanlarından sözleşmeli devlet memuru ve kadrolu devlet memuru statüsünde bulunanlara uygulanmıştır. Veriler kolayda örnekleme yöntemi kullanılarak elde edilmiştir. Demografik özelliklere yönelik bilgiler Tablo 1'de gösterilmiştir. Katılımcıların \%79'u erkek, \%21'i kadındır. Katılımcıların \%64'ü 10 yıl ve üstü, \%11'i 7-9 yıl, \%16'sı 3-7 yıl ve \%7'si 1-3 yıl arasında tecrübeye sahiptir. Katılımcıların \%21,3 lisansüstü, \%50,2'si lisans, \%12,6'sı ön lisans, \%14'ü lise eğitim derecesine sahiptir. Katılımcıların \%1,4'ü 18-25, \%43'ü 25-35, \%30'u 35-45, \%23,7'si 45-55 ve \%1,9'u 55 yaş ve üstüdür.

Tablo 1. Demografik Özellikler

\begin{tabular}{clcc}
\hline Değişkenler & & N (207) & \% \\
\hline Cinsiyet & Erkek & 165 & 79 \\
& Kadın & 42 & 21 \\
\hline \multirow{5}{*}{ Yaş } & $18-24$ & 3 & 1,4 \\
& $25-35$ & 89 & 43 \\
& $36-45$ & 62 & 30 \\
& $46-55$ & 49 & 23,7 \\
& 55 ve üstü & 4 & 1,9 \\
\hline \multirow{5}{*}{ Eğitim } & Illkokul & 4 & 1,9 \\
& Lise & 29 & 14 \\
& Ön-Lisans & 26 & 12,6 \\
& Lisans & 104 & 50,2 \\
& Lisansüstü & 44 & 21,3 \\
\hline \multirow{5}{*}{ Tecrübe } & $1-3$ yıl & 14 & 6,8 \\
& $4-6$ yıl & 12 & 5,8 \\
& $7-9$ yıl & 22 & 10,6 \\
& $10-12$ yıl & 24 & 11,6 \\
& 13 ve üstü yıl & 134 & 64,7 \\
\hline
\end{tabular}

\subsection{Veri Toplama Araçları}

Çalışmada veri toplama aracı olarak anket formu kullanılmıştır. Bu formlar online olarak tasarlanmış ve katılımcılara ulaştırılmıştır. Araştırma kapsamında toplam 27 maddeden oluşan 3 ölçek kullanılmıştır. Anket dört bölümden oluşmaktadır. Birinci kısımda demografik bilgiler, ikinci kısımda temel benlik değerlendirmesi ölçeği, üçüncü kısımda iş tatmini ölçeği ve dördüncü kısımda psikolojik iyi oluş ölçeği yer 
almaktadır. Kullanılan ölçeklerin her biri Ölçek $5^{\prime} l i$ Likert tarzında şu şekilde sunulmuştur: $1=$ Kesinlikle Katılmıyorum, 2=Katılmıyorum, 3=Kararsızım, 4=Katılıyorum, 5=Kesinlikle Katılıyorum.

Temel Benlik Değerlendirmesi Ölçeği 12 madde ile özsaygı, öz yeterlilik, kontrol odağı ve duygusal denge olmak üzere 4 boyutlu olup; ilk defa Judge vd. (2003) tarafından geliştirilmiş ve uygulanmış bir ölçektir. Ölçek ilk olarak Kisbu (2006) tarafından Türkçe'ye uyarlanmıştır. Ölçeğin Cronbach Alpha güvenilirlik katsayısı Judge vd. (2003) tarafından 0,80 bulunmuşken, Kisbu (2006) tarafından ise 0,70 olarak bulunmuştur. Ölçeğin her boyutu eşit sayıda maddeden oluşmaktadır. Maddelerden 6 tanesi $(2,4,6,8,10$, 12. maddeler) ters kodlanmıştır. "Işsleri başarıyla tamamlarım" ifadesi ölçekte kullanılan maddelerden birine örnek olarak verilebilir.

iş Tatmini Ölçeği Saylan (2008) tarafından geliştirilmiş olup 10 maddeden oluşmaktadır. Ölçeğin Cronbach Alpha güvenilirlik katsayısı 0,76 olarak bulunmuştur. Ölçekte ters puanlanmış madde bulunmamaktadır. "Işsimi severek yaparım" ifadesi ölçekte kullanılan maddelerden birine örnek olarak verilebilir.

Psikolojik Iyi Oluş Ölçeği Diener vd. (2010) tarafından 8 madde halinde oluşturulmuştur. Ölçek ilk olarak Telef (2013) tarafından Türkçeye uyarlanmıştır. Yapılan uyarlama çalışmalarında ölçeğin Cronbach Alpha güvenilirlik katsayısı 0,80 olarak bulunmuştur. "Insanlar bana saygı duyar" ifadesi ölçekte kullanılan maddelerden birine örnek olarak verilebilir.

\section{Bulgular}

\section{1. Ölçeklerin Geçerlilikleri ve Güvenilirlikleri}

Araştırmada yapılan analizler, SPSS 22.0 ve Amos 22.0 yazılımı kullanılarak gerçekleştirilmiştir. Temel benlik değerlendirmesi (TBD), iş tatmini ve psikolojik iyi oluş ölçeklerin geçerliliklerini tespit etmek için doğrulayıcı faktör analizinden faydalanılmıştır. Tespit edilen uyum iyiliği değerleri Tablo 2'de gösterilmiştir.

TBD ölçeği dört boyutlu haliyle analize sokulmuş fakat istenen ve beklenen değerlere ulaşılamaması sonucunda 1. ve 9. maddeler çıkartılarak tek boyut halinde analiz edilmiştir. Tablo 2'de görüldüğü gibi yapılan DFA sonucunda, ölçeğin 10 maddelik tek faktörlük yapısı doğrulanmıştır $\left(\chi^{2} / d f=1,9 ; R M S E A=0,066 ; C F I=\right.$ $0,91 ; \mid \mathrm{FI}=0,91 ; \mathrm{GFI}=0,94)$. Bu çalışmada temel benlik değerlendirmesinin bütününün Cronbach Alpha güvenilirlik katsayısı 0,72 olarak tespit edilmiştir. Judge vd. (2003) tarafından saptanan Cronbach Alpha güvenilirlik katsayı ise $0,80^{\prime}$ dir.

İ̧ tatmini ölçeğinde bulunan 8., 9. ve 10. maddeler faktör yüklerinin düşük olmasından dolayı ölçekten çıkartılarak, bir maddede hata birleştirilmesi yapılmıştır. Tablo 2'de görüldüğü gibi yapılan DFA sonucunda, ölçeğin 7 maddelik tek boyutlu yapısı doğrulanmıştır $\left(\chi^{2} / d f=2,2 ; R M S E A=0,077 ; C F I=0,97 ; I F I=\right.$ $0,96 ; \mathrm{GFI}=0,97)$. Çalışmada iş tatmini ölçeğinin Cronbach Alpha güvenilirlik katsayısı 0,86 olarak saptanmıştır.

Psikolojik iyi oluş ölçeğinde ölçek maddeleri arasında bir maddede hata birleştirmesi yapılmış, herhangi bir madde atımı yapılmamıştır. Tablo 2' de görüldüğü gibi yapılan DFA sonucunda, ölçeğin 8 maddelik tek boyutlu yapısı doğrulanmıştır ( $\left.\chi^{2} / \mathrm{df}=1,9 ; \mathrm{RMSEA}=0,068 ; \mathrm{CFI}=0,96 ; \mid F I=0,96 ; \mathrm{GFI}=0,96\right)$. Bu çalışma kapsamında ölçeğin güvenirlik katsayısı 0,79 olarak bulunmuştur.

Araştırmada kullanılan ölçeklerin DFA sonuçlarına göre (Tablo 2) ölçekler yapı geçerliliğini sağlamaktadır (Byrne, 2001). Doğrulayıcı faktör analizinde, $\chi^{2} / \mathrm{df}$ değerinin 3'ün altında olması, GFI ve CFI değerlerinin 0,90 ve üzerinde olması, RMSEA değerinin ise $0,08^{\prime}$ in altında olması ölçüm modelinin verilere iyi uyum sağladığını göstermektedir (Schumacker ve Lomax, 2010). Ayrıca, hesaplanan Cronbach Alpha değerlerine göre (Tablo 2) ölçekler güvenilir bulunmuştur (Nunnally, 1978). 
Tablo 2. Ölçeklerin Doğrulayıcı Faktör Analizi Sonuçları

\begin{tabular}{|c|c|c|c|c|}
\hline Ölçek & Index & Mükemmel Uyum Ölçütü & Kabul Edilebilir Uyum Ölçütü & $\begin{array}{l}\text { Araştırma } \\
\text { Bulgusu }\end{array}$ \\
\hline \multirow{5}{*}{$\begin{array}{l}\text { Temel Benlik } \\
\text { Değerlendirmesi }\end{array}$} & $\chi^{2} / s d$ & $0-3$ & $3-5$ & 1,9 \\
\hline & RMSEA & $0,00 \leq \mathrm{RMSEA} \leq 0,05$ & $0,05 \leq \mathrm{RMSEA} \leq 0,10$ & 0,06 \\
\hline & CFI & $0,95 \leq \mathrm{CFI} \leq 1,00$ & $0,90 \leq \mathrm{CFI} \leq 0,95$ & 0,91 \\
\hline & IFI & $0,95 \leq \mathrm{CFI} \leq 1,00$ & $0,90 \leq \mathrm{CFI} \leq 0,95$ & 0,91 \\
\hline & GFI & $0,95 \leq \mathrm{CFI} \leq 1,00$ & $0,90 \leq \mathrm{CFI} \leq 0,95$ & 0,94 \\
\hline \multirow{5}{*}{ Psikolojik İyi Oluş } & $\chi^{2} / s d$ & $0-3$ & $3-5$ & 1,9 \\
\hline & RMSEA & $0,00 \leq \mathrm{RMSEA} \leq 0,05$ & $0,05 \leq \mathrm{RMSEA} \leq 0,10$ & 0,06 \\
\hline & $\mathrm{CFI}$ & $0,95 \leq \mathrm{CFI} \leq 1,00$ & $0,90 \leq \mathrm{CFI} \leq 0,95$ & 0,96 \\
\hline & $\mathrm{IFI}$ & $0,95 \leq \mathrm{CFI} \leq 1,00$ & $0,90 \leq \mathrm{CFI} \leq 0,95$ & 0,96 \\
\hline & GFI & $0,95 \leq \mathrm{CFI} \leq 1,00$ & $0,90 \leq \mathrm{CFI} \leq 0,95$ & 0,96 \\
\hline \multirow{5}{*}{ İş Tatmini } & $\chi^{2} / s d$ & $0-3$ & $3-5$ & 2,2 \\
\hline & RMSEA & $0,00 \leq \mathrm{RMSEA} \leq 0,05$ & $0,05 \leq \mathrm{RMSEA} \leq 0,10$ & 0,07 \\
\hline & $\mathrm{CFI}$ & $0,95 \leq \mathrm{CFI} \leq 1,00$ & $0,90 \leq \mathrm{CFI} \leq 0,95$ & 0,97 \\
\hline & $\mathrm{IFI}$ & $0,95 \leq \mathrm{CFI} \leq 1,00$ & $0,90 \leq \mathrm{CFI} \leq 0,95$ & 0,96 \\
\hline & GFI & $0,95 \leq \mathrm{CFI} \leq 1,00$ & $0,90 \leq \mathrm{CFI} \leq 0,95$ & 0,97 \\
\hline
\end{tabular}

Not: $\chi^{2}=$ Normal Theory Weighted Least Squares Chi-Square (Ki Kare), $d f=$ Degrees of Freedom (Serbestlik Derecesi), RMSEA $=$ Root Mean Square Error of Approximation (Yaklaşık Hataların Ortalama Karakökü), CFI = Comparative Fit Index (Karşılaştırılmalı Uyum Indeksi), IFI = Incremental Fit Index (Fazlalık Uyum indeksi), GFI= Goodness of Fit Index (İilik Uyum Indeksi)

\subsection{Tanımlayıcı İstatistikler ve Değişkenler Arası Iliş̧iler}

Değişkenlere ait ortalama, standart sapma, çarpıklık ve basıklık değerleri, korelasyon değerleri ve güvenilirlik katsayıları Tablo 3'te verilmiştir.

Tablo 3. Değişkenlere Ait Ortalama, Standart Sapma, Çarpıklık ve Basıklık Değerleri, Korelasyon Değerleri

\begin{tabular}{|l|c|c|c|c|c|c|}
\hline Değişkenler & Ort. & SS & Çarpıklık/Basıklık & $\mathbf{1}$ & $\mathbf{2}$ & $\mathbf{3}$ \\
\hline 1. Temel Benlik Değerlendirmesi & 3,55 & 0,518 & $-0,009 / 0,146$ & $(0,72)$ & & \\
\hline 2. Psikolojik İyi Oluş & 3,64 & 0,524 & $0,735 / 0,949$ & $0,43^{* *}$ & $(0,79)$ & \\
\hline 3. İ̧ Tatmini & 3,41 & 0,797 & $-0,618 /-0,203$ & $0,37^{* *}$ & $0,34^{* *}$ & $(0,86)$ \\
\hline
\end{tabular}

**: $p<0,01$. Parantez içindeki değerler değişkenlerin güvenilirlik katsayılarını göstermektedir.

Tablo 3'teki değişkenler incelendiğinde katılımcıların TBD düzeylerinin 3,55 (SS=0,518) aritmetik ortalama ile yüksek sayılabilecek bir düzeyde olduğu tespit edilmiştir. Bu ölçekten alınabilecek maksimum puanın 5 olduğu dikkate alındığında, örneklemde yer alan katılımcıların TBD düzeylerinin orta üstü bir değer taşıdığı gözlemlenmektedir. Katılımcıların psikolojik iyi oluş düzeylerinin ise 3,64 (SS=0,524) aritmetik ortalama ile en yüksek ortalamaya sahip olduğu söylenebilir. İş tatmini düzeylerinin ise $3,41(S S=0,797)$ ortalama değere sahip olduğu tespit edilmiştir. Nitekim bu değer de diğer değişkenlerdeki değerler gibi orta seviyenin üzerinde bir ortalamaya sahiptir.

Verilerin normallik varsayımının sınanması için ilgili ölçeklerden elde edilen puan ortalamalarının çarpıklık ve basıklık katsayıları incelenmiştir. Buna göre ölçeklerin çarpıklık ve basıklık katsayıları +1 ile -1 aralığında değişmektedir. Dolayısıyla verilerin normal dağılım gösterdiği anlaşılmaktadır (Tabachnick ve Fidell, 2012).

Değişkenler arası ilişkilerin hesaplanmasında Pearson korelasyon analizi kullanılmıştır. Yapılan analizlerin sonuçlarına göre araştırmaya konu olan tüm değişkenler arasında pozitif yönlü anlamlı ilişkiler söz 
konusudur. Tablo 3 incelendiğinde TBD'nin $(r=0,43 ; p<0,01)$ psikolojik iyi oluş ve iş tatmini $(r=0,37 ; p<0,01)$ ile ilişkisinin anlamlı olduğu belirlenmiştir. Ayrıca psikolojik iyi oluşun iş tatmini $(r=0,34 ; p<0,01)$ ile anlamlı bir ilişkisinin olduğu da tespit edilmiştir.

\subsection{Hipotez Testlerine iliş̧kin Bulgular}

TBD’nin iş tatmini üzerine etkisinde, psikolojik iyi oluşun aracılık rolü olup olmadığı Hayes (2018) tarafından geliştirilen Process makrosu kullanılarak test edilmiştir. Bu kapsamda bootstrap yöntemini temel alan regresyon analizi gerçekleştirilmiş ve özellikle bu yöntemin Baron ve Kenny (1986)'nin geleneksel nedensel adımlar yönteminden ve Sobel testinden daha güvenilir sonuçlar verdiği birçok yazar tarafından iddia edilmiştir (Zhao vd., 2010; Preacher vd., 2011; Hayes, 2018; Gürbüz, 2019). Analizlerde bootstrap yeniden örnekleme seçeneği kullanılmıştır. Bootstrap tekniği kullanılarak gerçekleştirilen analizlerde, aracı etki hipotezlerinin desteklenmesi ancak \%95 güven aralı̆ındaki (confidence interval, $\mathrm{Cl}$ ) değerlerin (0) sıfır değerini kapsamaması halinde mümkün olmaktadır (MacKinnon vd., 2004). Buna ek olarak bootstrap tekniği kullanılarak yapılan analizlerde aracılık rolünün seviyesi tam standardize etki $\left(K^{2}\right)$ değerine bakılarak anlaşılabilmektedir. Tam standardize etki olan $\mathrm{K}^{2}=0,01^{\prime}$ e yakın bir değer almış ise düşük etki, $\mathrm{K}^{2}=0,09^{\prime}$ a yakın ise orta etki, $K^{2}=0,25^{\prime}$ e yakın ise yüksek etki şeklinde yorumlanmaktadır (Preacher vd., 2011).

Process makrosu kullanılarak gerçekleştirilen aracılık analizlerinde öncelikli odak noktası dolaylı ve doğrudan etki değerlerinin hesaplanması ve hesaplanan değerlerden çıkarımlar yapılmasıdır. Dolaylı etki, bağımsız değişkenin (TBD), aracı değişken üzerindeki etkisi ile aracı değişkenin (Psikolojik iyi oluş), bağımlı değişken (iş̧ tatmini) üzerindeki etkisinin çarpımıdır. Bootstrap testi sonucunda bağımsız değişkenin (TBD) bağımlı değişken (iş̧ tatmini) üzerindeki dolaylı etkinin anlamlı olması durumda aracılık modeli doğrulanmış kabul edilmektedir (Gürbüz, 2019).

Baron ve Kenny (1986)'nin yöntemi doğrultusunda oluşturulan birçok hipotez "tam aracı" ve "kısmi aracı" şeklinde oluşturulmuştur. Ancak bu tür betimlemelerin örneklem sayısına oldukça duyarlı olduğundan kullanılmaması gerektiği vurgulanmıştır (Darlington ve Hayes, 2017). Araştırılan aracılık modelinin ta m aracılık modeli olduğu bulgusuna ulaşılmış olması demek o modeldeki bağımsız değişken ile bağımlı değişken arasında incelenen aracılık modelinde yer almayan diğer aracı değişkenlerin olduğu veya olmadığı yönünde bir yargıya varılmasına işaret etmemektedir (Rucker vd., 2011). Dolayısıyla kısmi aracılık veya tam aracılık kavramlarının oluşturulan hipotezlerde kullanımından kaçınılması önerilmektedir (Hayes, 2018).

Bu kapsamda TBD’nin iş tatmini üzerine etkisinde psikolojik iyi oluşun aracılık rolünü tespit etmeye yönelik analiz sonuçları Tablo 4'te gösterilmiştir.

Tablo 4. Bootstrap Regresyon Analizi Sonuçları

\begin{tabular}{|c|c|c|c|c|c|c|}
\hline \multirow[b]{2}{*}{ Değişkenler } & \multicolumn{3}{|c|}{ Psikolojik İyi Oluş } & \multicolumn{3}{|c|}{ İş Tatmini } \\
\hline & $b$ & $L L C I$ & ULCI & $b$ & $\mathrm{LLCl}$ & ULCI \\
\hline Sabit & 2,200 & 1,773 & 2,658 & 1,394 & 0,688 & 2,101 \\
\hline TBD & $0,403^{* *}$ & 0,2806 & 0,5354 & $0,568^{* * *}$ & 0,372 & 0,765 \\
\hline Psikolojik İyi Oluş & & & & $0,348^{* * *}$ & 0,140 & 0,556 \\
\hline $\mathrm{R}^{2}$ & \multicolumn{3}{|c|}{0,162} & \multicolumn{3}{|c|}{0,180} \\
\hline Bootstrap Dolaylı Etki & \multicolumn{6}{|c|}{ TBD $\rightarrow$ P. İyi Oluş $\rightarrow$ İş Tatmini } \\
\hline
\end{tabular}

** $p<0,01, * * * p<0,001 ;$ S.H.: Standart Hata. Standardize edilmemiş beta (b) katsayıları raporlanmıştır.

Yapılan analizlerin ilkinde TBD'nin psikolojik iyi oluşu etkisi, ikincisinde ise psikolojik iyi oluşun iş tatminine etkisi ve TBD'nin iş tatminine etkisi test edilmiştir. Analiz sonuçları Tablo 4'te verilmiştir. Tablo 4'te gösterilen sonuçlara göre, TBD'nin doğrudan iş tatminine etkisinin ( $b=0,568,95 \% \mathrm{BCA} \mathrm{Cl}[0,009,0,029])$ pozitif olduğu görülmektedir. Bu tespit ile beraber $\mathrm{H}_{1}$ hipotezi desteklenmiştir. TBD’nin çalışan bireylerin psikolojik iyi oluşlarına etkisinin ( $b=0,403,95 \% \mathrm{BCA} \mathrm{Cl}[0,280,0,535])$ pozitif olduğu tespit edilmiştir. Dolayısıyla bu veriler ışı̆ıında $\mathrm{H}_{2}$ hipotezi de desteklenmiştir. Çalışanların psikolojik iyi oluşlarının iş 
tatminlerine etkisinin $(b=0,348,95 \% \mathrm{BCA} \mathrm{Cl}[0,140,0,556])$ pozitif olduğu görülmektedir. Bu tespit ile $\mathrm{H}_{3}$ desteklenmiştir.

Son olarak, TBD’nin iş tatminine etkisinde, psikolojik iyi oluşun aracılık rolü olup olmadığını test etmek amacıyla bootstrap yöntemini esas alan regresyon analizi yapılmıştır. Analizlerde bootstrap tekniği ile 5000 yeniden örneklem seçeneği tercih edilmiştir. TBD’nin iş tatmini üzerinde dolaylı etkisinin anlamlı olduğu, dolayısıyla da psikolojik iyi oluşun, TBD ile iş tatmini arasındaki ilişkiye aracılık ettiği tespit edilmiştir ( $b=0,14$, $95 \% \mathrm{BCA} \mathrm{Cl}[0,036,0,249])$. Nitekim analiz sonucunda düzeltilmiş yanlılık ve hızlandırılmış güven aralığı değerleri ( $\mathrm{BCA} \mathrm{Cl})$ sıfır değerini kapsamamaktadır. Tam standardize etki büyüklüğü $\left(\mathrm{K}^{2}\right)$ 0,92 olup bu değerin orta değere yakın bir etki büyüklüğü olduğu söylenebilmektedir. Bu sonuçlar ışığında araştırmanın temel hipotezi olan $\mathrm{H}_{4}$ desteklenmiştir.

\section{Sonuç}

Bu çalışmada, temel benlik değerlendirmesinin iş tatminini nasıl etkilediğini ortaya koymak ve bu etkide psikolojik iyi oluşun oynadığı rolü belirlemek amaçlanmıştır. Buna ek olarak TBD'nin bireylerin psikolojik iyi oluşları üzerindeki muhtemel etkisini, bireylerin psikolojik iyi oluşlarının iş tatmin düzeylerine anlamlı bir etkisinin olup olmadığı, bir ilçe belediyesi bünyesinde bulunan beyaz yakalı işgörenlerden oluşan bir örneklem üzerinde incelenmiştir.

Araştırmanın bulgularından birincisi, TBD’nin bireylerin iş tatminleri üzerinde olumlu ve anlamlı bir etkisi olduğunu ortaya koymuştur. TBD'nin iş tatmini üzerinde pozitif bir etkisi olduğu anlaşılmıştır. Elde edilen bulgular, Judge vd. (1997) ve Gürbüz vd. (2010) tarafından yapılan araştırma sonuçları ile uyumlu olduğunu göstermektedir. Bireylerin iş tatminlerinin özellikle toplulukçu olan kültürlerde iş özelliklerine bağı olduğu ifade edilmiştir (Diener ve Diener, 1995; Oishi vd., 1999). Toplulukçu kültürün hâkim olduğu Türkiye ve Japonya gibi ülkelerde yapılan çalışmalarda TBD'nin iş tatminini olumlu ve anlamlı yordadığı tespit edilmiştir (Piccolo vd., 2005; Gürbüz vd., 2010). Dolayısıyla çalışanların, TBD'nin boyutları arasında sayılan, öz yeterlilik, özsaygı, kontrol odağı ve duygusal denge algılarının yüksek olması işlerinden daha fazla tatmin olmalarını sağlayacağı söylenebilmektedir.

Araştırma bulgularından ikincisi, TBD’nin bireylerin psikolojik iyi oluşları üzerinde olumlu ve anlamlı bir etkisi olduğunu ortaya koymuştur. Buradan hareketle, bireylerin TBD düzeylerinin artışı iyi oluş seviyelerini artırdığı söylenebilmektedir. TBD’nin boyutları ile psikolojik iyi oluş arasındaki ilişkinin ortaya konulduğu çalışma sonuçları incelendiğinde anlamlı etkilerin olduğu görülmektedir. Nitekim; TBD’nin boyutlarından biri olan öz yeterlilik, kişinin bir işi gerçekleştirmeden önce o iş için kabiliyetinin yetip yetmediğine olan inancıdır (Bandura, 1995). Bandura (1995)'nın Öz Yeterlilik Kuramı'nda bireylerin başarabileceklerine inandıkları işlere girmeye kolayca ikna olabildiği, başaramayacağı işlere ise eğilim göstermedikleri belirtilmiştir. Buradan hareketle, başarabileceklerine inandıkları işlerde çalışan, dolayısıyla öz yeterliliği yüksek olan bireylerin iyi oluş seviyelerinin de yükseleceği ifade edilebilir (Caprara vd., 2006; van Zly ve Dhurup, 2018). Bir başka boyut olan özsaygının iyi oluşla yüksek derecede ilişkisi bulunmuş (Furnham ve Cheng, 2000), yüksek özsaygının daha yüksek düzeyde iyi oluşa ulaştırdığı ifade edilmiştir (Baumeister vd., 2003). Bireylerin duygusal denge düzeyleri ile iyi oluşlarının da birbiriyle anlamlı ilişkisi tespit edilmiş (Argly ve Lu, 1990) ve iyi oluşu etkileyen önemli etkenlerden birinin de duygusal denge olduğu ifade edilmiştir (Hills ve Argly, 2001). Son olarak TBD’nin bir diğer boyutu olan kontrol odağının da bireylerin iyi oluşları ile ilişkili olduğu saptanmıştır (Ramezani ve Gholtash, 2015).

Araştırmanın üçüncü bulgusu ile bireylerin psikolojik iyi oluşlarının iş tatminlerini olumlu anlamda etkilediği ortaya konulmuştur. Bireylerinin iyi oluş seviyeleri arttıkça işten aldıkları tatmin seviyelerinin artacağı tespit edilmiştir. Bireylerin iyi oluşlarının iş tatminleri üzerinde olumlu ya da olumsuz bir etkiye sahip olduğu kaçınılmazdır (Bakan ve Büyükmeşe, 2004). Kendilerini iyi hisseden bireylerin çevreleriyle iyi ilişkiler kurduğu, yaratıcılık seviyelerinin yüksek olduğu ve iş yaşamlarında başarılı oldukları tespit edilmiştir (Lyubomirsky vd., 2005). Çalışanların iyilik halleri işe yönelik olumlu düşünceler taşımalarını sağlayarak, iş tatmini seviyelerini artırmaktadır (Limbert, 2004). Bireylerin iyi oluş ve iş tatminleri üzerine yapılan bir 
çalışmada, çalışan kadınların iyi oluş seviyeleri arttıkça işten aldıkları tatminin arttığı görülmüştür (Işık vd., 2017).

Araştırmanın temel hipotezi olan dördüncü bulgu, TBD’nin iş tatminine etkisinde psikolojik iyi oluşun aracılık rolünü ortaya koymuştur. Bireylerin TBD'nin olumlu düzeylerde olması daha fazla iş tatmini sağlamalarını etkilerken, bu etkiye psikolojik iyi oluş hallerinin orta derecede aracılık ettiği söylenebilmektedir $\left(K^{2}=0,92\right)$. Literatürde bu aracılık rolünü ortaya çıkaran başka bir çalışma bulunmamaktadır. Dolayısıyla bu araştırmanın örgütsel davranış yazınına özgün bir çıktı sağladığını söylemek mümkündür. Ayrıca TBD’nin iş tatminine etkisinde kariyer bağlıığının da aracılık ettiği tespit edilmiştir (Zhang vd., 2014). Aracılık rolünü mutluluk kuramlarından Ereksel ve Etkinlik Kuramları arasındaki farkı açıklayarak temellendirmek mümkündür. Ereksel Kuram; iyi oluşu, amaç ve ihtiyaç kavramları çerçevesinde açıklamaya çalışmış, bireylerin belirlediği hedeflerine yönelik ulaştığı başarı olarak nitelendirmiştir (Diener, 1984). Etkinlik Kuramı ise mutluluğu, ulaşılan son nokta olarak değil; mutluluğun, insan aktivitesinin bir ürünü olduğunu, bireylerin davranışlarından kaynaklandığını vurgulamaktadır (Diener, 1984). Bireyin iyi oluş halinin aslında sonuç değil, bir süreç olduğu anlaşılmaktadır.

İş tatmini tüm örgütler için hayati öneme sahip bir unsurdur. Kamusal hizmetlerin yerel unsurlarından biri olan belediyeler, hizmet sektörünün en önemli lokomotiflerinden biridir. Belediyeler, etki alanları ve bünyesinde bulundurdukları çalışan sayıları ile yerel alanda kritik bir rol oynamaktadır. Çalışanlar, halkla bire bir iletişime giren, sorunlarını dinleyen, çözüm arayan; halkla ilişkiler birimi, imar ve şehircilik hizmetleri, fen işleri, temizlik hizmetleri, ruhsat ve denetim ekipleri, İnsan kaynakları ve zabıta hizmetleri ile geniş yelpazede hizmet vermektedir. Yürütülen araştırma neticesinde, TBD'nin bireylerin iş tatminlerini psikolojik iyi oluşun aracılık etkisiyle artırdığı tespit edilmiştir. Bu bağlamda beyaz yakalı belediye çalışanlarının öz yeterliliklerinin, özsaygılarının, kontrol odağının ve duygusal denge durumlarının olumlu düzeylerde olması, iyi oluş seviyelerinin de aracılık rolüyle işten tatmin olmalarını sağlayacaktır. Bu noktada belediye yöneticilerinin; çalışanların TBD, işten duydukları tatmin ve iyi oluş düzeylerini dikkate almaları gerekliliği gerçeği ortaya çıkmaktadır. Çünkü çalışma şartlarındaki olumsuzluklar, stresli ve riskli çalışma ortamları, yöneticilerin duyarsızlığı iş tatminsizliğine yol açan etkenlerden olduğu düşünülmektedir (Karcıoğlu vd., 2009). Bireylerin bu etkenleri ortadan kaldırabilmesi veya olumsuzluklarla başa çıkabilmesi için benlik değerlendirmesinin olumlu ve yüksek düzeyde olması gerekmektedir (Morris vd., 2013). Nitekim bunun hizmet ağı geniş olan belediyelerin amaçlarına ulaşmasında kritik bir öneme sahip olduğu söylenebilmektedir.

Araştırmada birtakım kısıtlardan bahsetmek mümkündür. İlk olarak, araştırma, İstanbul'da bulunan bir ilçe belediyesinde çalışan sınırlı sayıdaki $(N=207)$ beyaz yakalı iş görenler üzerinde yapılmıştır. Sonraki araştırmaların daha geniş çapta ve farklı sektörlere yönelik örneklem grupları ile gerçekleştirilmesi, araştırmanın çıktılarının daha güvenilir ve kabul edilebilir hale gelmesi için faydalı olacaktır. Araştırmanın özdeğerlemeye dayalı olması ve verilerin kesitsel tarzda toplanması diğer bir kısıttır.

Araştırmacıların, özellikle TBD'nin alt boyutlarının örgütsel bağlılık, örgütsel yabancılaşma ve örgütsel vatandaşık gibi iş çıktıları ile ilişkisini araştırması daha detaylı sonuçlara ulaşmayı sağlayabilir. Bu çalışma, TBD'nin iş tatminine etkisinde psikolojik iyi oluşun aracılık rolünü saptamıştır. Fakat TBD'nin iş tatminine etkisinde aracılık rolü bulunan örgüt iklimi, bilinçli farkındalık, içsel motivasyon gibi birçok değişkenin var olduğu düşünülmektedir. Yine TBD’nin iş tatminine etkisinde düzenleyici etkileri saptamak için cinsiyet, yaş ve kıdem gibi demografik değişkenlerin rolünün araştırılması önerilmektedir.

\section{Beyan ve Açıklamalar (Disclosure Statements)}

1. Bu çalışmanın yazarları, araştırma ve yayın etiği ilkelerine uyduklarını kabul etmektedirler (The authors of this article confirm that their work complies with the principles of research and publication ethics).

2. Yazarlar tarafından herhangi bir çıkar çatışması beyan edilmemiştir (No potential conflict of interest was reported by the authors).

3. Bu çalışma, intihal tarama programı kullanılarak intihal taramasından geçirilmiştir (This article was screened for potential plagiarism using a plagiarism screening program). 


\section{Kaynaklar}

Achor, S. (2011). The happiness advantage: The seven principles of positive psychology that fuel success and performance at work. Random House.

Aiello, A., \& Tesi, A. (2017). Psychological well-being and work engagement among Italian social workers: Examining the mediational role of job resources. Social Work Research, 41(2), 73-84.

Akdemir, B., \& Açan, A. M. (2017). Psikolojik sermaye ve iş tatmini ilişkisini belirlemeye yönelik bir araştırma. Akademik Yaklaşımlar Dergisi, 8(2), 57-79.

Akdoğan, A., \& Polatçı, S. (2013). Psikolojik sermayenin performans üzerindeki etkisinde iş aile yayılımı ve psikolojik iyi oluşun etkisi. Atatürk Üniversitesi Sosyal Bilimler Enstitüsü Dergisi, 17(1), 273-293.

Akgün, Z. (2019). Erkeklerde toplumsal cinsiyet normlarına uyum, motivasyon ve psikolojik iyi oluş ilişkisi. Dünya Multidisipliner Araştırmalar Dergisi, 2019(2), 1-38.

Ajibola, K. (2020). Link between employees' locus of control, job satisfaction, and job stress among teachers: A survey analysis in Osun State of Nigeria. Olonade, Z., Ajibola, K., Oyewumi, O., Olusesi, L., \& Bamidele, D. (2020). Link between employees' locus of control, job satisfaction, and job stress among teachers: A survey analysis in Osun State of Nigeria. Quest Journal of Management and Social Sciences, 2(1), 21-34.

Angelova, N. V. (2016). Locus of control and its relationship with some social-demographic factors. Psychological Thought, 9(2), 248-258.

Argyle, M., \& Lu, L. (1990). Happiness and social skills. Personality and Individual Differences, 11(12), 1255-1261.

Arslan, E. T., \& Demir, H. (2017). İşe angaje olma ve iş tatmini arasındaki ilişki: Hekim ve hemşireler üzerine nicel bir araştırma. Yönetim ve Ekonomi, 24(2), 371-389.

Awang, A., Ibrahim, I. I., Nor, M. N. M., Razali, M. F. M., Arof, Z. M., \& Rahman, A. R. A. (2015). Academic factors and turnover intention: Impact of organization factors. Higher Education Studies, 5(3), 24-44.

Bakan, í., \& Büyükbeşe, T. (2004). Örgütsel iletişim ile iş tatmini unsurları arasındaki ilişkiler: Akademik örgütler için bir alan araştırması. Akdeniz Üniversitesi Iktisadi ve Idari Bilimler Fakültesi Dergisi, 4(7), 1-30.

Bandura, A. (1995). Self-efficacy in changing societies. Cambridge: Cambridgem University Press.

Baron, R. M., \& Kenny, D. A. (1986). The moderator-mediator variable distinction in social psychological research: Conceptual, strategic, and statistical considerations. Journal of Personality and Social Psychology, 51(6), 11731182.

Baumeister, R. F., Campbell, J. D., Krueger, J. I., \& Vohs, K. D. (2003). Does high self-esteem cause better performance, interpersonal success, happiness, or healthier lifestyles? Psychological Science in the Public Interest, 4(1), 1-44.

Bowling, N. A., Eschleman, K. J., \& Wang, Q. (2010). A meta-analytic examination of the relationship between job satisfaction and subjective well-being. Journal of Occupational and Organizational Psychology, 83(4), 915-934.

Büyükdüvenci, S. (1993). Aristotales'te mutluluk kavramı. Felsefe Dünyası, 9, 41-45.

Byrne, B. M. (2001). Structural equation modeling with amos: Basic concepts, applications, and programming. London: Mahwah NJ.

Caprara, G. V., Steca, P., Gerbino, M., Paciello, M., \& Vecchio, G. M. (2006). Looking for adolescents' well-being: Selfefficacy beliefs as determinants of positive thinking and happiness. Epidemiology and Psychiatric Sciences, 15(1), 30-43.

Chen, J. C., \& Silverthorne, C. (2008). The impact of locus of control on job stress, job performance and job satisfaction in Taiwan. Leadership \& Organization Development Journal, 29(7), 572-582.

Curhan, J. R., Elfenbein, H. A., \& Kilduff, G. J. (2009). Getting off on the right foot: Subjective value versus economic value in predicting longitudinal job outcomes from job offer negotiations. Journal of Applied Psychology, 94, 524534.

Çakmak Otluoğlu, K. Ö. (2015). Örgütsel nedenlerle yaşanan olumsuz şokların iş performansına etkisi: Örgüt temelli özsaygının biçimlendirici değişken rolü. ODTÜ Gelişme Dergisi, 42(8), 221-246.

Çırakoğlu, O. C., \& Tezer, E. (2010). Kontrol odağı ve eleştirel düşünmenin üniversite öğrencilerinin ilişki doyumsuzluklarına verdikleri tepkiler üzerindeki yordayıcı rolü. Türk Psikoloji Yazıları, 13(26), 29-41.

Darlington, R. B., \& Hayes, A. F. (2017). Regression analysis and linear models: Concepts, applications, and implementation. New York: The Guilford Press

Diener, E. (1984). Subjective well being. Psychological Bulletin, 95(3), 542-575. 
Diener, E., \& Diener, M. (1995). Cross-cultural correlates of life satisfaction and self-esteem. Personality Processes and Individual Differences, 68, 653-663.

Diener, E., Wirtz, D., Tov, W., Kim-Prieto, C., Choi, D. W., Oishi, S., \& Biswas-Diener, R. (2010). New well-being measures: Short scales to assess flourishing and positive and negative feelings. Social Indicators Research, 97(2), 143-156.

Doğan, T., \& Eryılmaz, A. (2013). Benlik saygısı ve öznel iyi oluş arasındaki ilişkilerin incelenmesi. Pamukkale Üniversitesi Eğitim Fakültesi Dergisi, 33(33), 107-117.

Erez, A., \& Judge, T. A. (2001). Relationship of core self-evaluations to goal setting, motivation, and performance. Journal of Applied Psychology, 86, 1270-1279.

Erdirençelebi, M., \& Ertürk, E. (2018). Çalışanların örgütsel yalnızlık algısının iş tatmini ve işten ayrılma niyeti üzerine etkileri. Gaziantep University Journal of Social Sciences, 17(2), 603-618.

Ergeneli, A., \& Eryiğit, M. (2001). Öğretim elemanlarının iş tatmini: Ankara'da devlet ve özel üniversite karşılaştırması. Hacettepe Üniversitesi Iktisadi ve Idari Bilimler Fakültesi Dergisi, 19(2), 159-178.

Ertürk, A., Keskinkılıç Kara, S. B., \& Zafer Güneş, D. (2016). Duygusal emek ve psikolojik iyi oluş: Bir yordayıcı olarak yönetsel destek algısı. Abant Izzet Baysal Üniversitesi Eğitim Fakültesi Dergisi, 16(4), 1722-1744.

Eryılmaz, A., \& Atak, H. (2011). Ergen öznel iyi oluşunun öz saygı ve iyimserlik eğilimi ile ilişkisinin incelenmesi. Elektronik Sosyal Bilimler Dergisi, 10(37), 170-181.

Furnham, A., \& Cheng, H. (2000). Perceived parental behaviour, self-esteem and happiness. Social Psychiatry and Psychiatric Epidemiology, 35(10), 463-470.

Fredrickson, B. L. (2004). The broaden-and-build theory of positive emotions. Philosophical Transactions of the Royal Society of London. Series B: Biological Sciences, 359(1449), 1367-1377.

Gürbüz, S., \& Yüksel, M. (2008). Çalışma ortamında duygusal zeka: İş performansı, iş tatmini, örgütsel vatandaşlık davranışı ve bazı demografik özelliklerle ilişskisi. Doğuş Üniversitesi Dergisi, 9(2), 174-190.

Gürbüz, S. (2019). Sosyal bilimlerde aracı, düzenleyici ve durumsal etki analizleri. Ankara: Seçkin Yayıncılık.

Gürbüz, S., Erkuş, A., \& Sığrı, Ü. (2010). İş tatmini ve iş performansının yeni öncülü: Temel benlik değerlendirmesi. Sosyal ve Beşeri Bilimler Dergisi, 2(1), 69-76.

Hayes, A. F. (2018). Introduction to mediation, moderation, and conditional process analysis: A regression-based approach. New York: The Guilford Press.

Hills, P., \& Argyle, M. (2001). Emotional stability as a major dimension of happiness. Personality and Individual Differences, 31(8), 1357-1364.

Hlatywayo, C. K., Mhlanga, T. S., \& Zingwe, T. (2013). Neuroticism as a determinant of job satisfaction among bank employees. Mediterranean Journal of Social Sciences, 4(13), 549-549.

Holmbeck, G. N. (1997). Toward terminological, conceptual, and statistical clarity in the study of mediators and moderators: Examples from the child-clinical and pediatric psychology literatures. Journal of Consulting and Clinical Psychology, 65(4), 599-610.

Işık, Z., Çetinkaya, N., \& Işık, M. F. (2017). Mutluluğun iş tatmini üzerindeki rolü: Erzurum ili Palandöken kış turizm merkezinde yer alan konaklama işletmelerindeki kadın çalışanlar üzerine bir uygulama. Journal of Graduate School of Social Sciences, 21(2), 457-471.

Judge, T. A., \& Bono, J. E. (2001). Relationship of core self-evaluations traits-self-esteem, generalized selfefficacy, locus of control, and emotional stability-with job satisfaction and job performance: A meta-analysis. Journal of Applied Psychology, 86(1), 80-92.

Judge, T. A., Erez, A., Bono, J. E., \& Thoresen, C. J. (2003). The core self-evaluations scale: Development of a measure. Personnel Psychology, 56(2), 303-331.

Judge, T. A., Locke, E. A., \& Durham, C. C. (1997). The dispositional causes of job satisfaction: A core evaluations approach. Research in Organizational Behavior, 19, 151-188.

Karacaoğlu, K., \& Köktaş, G. (2016). Psikolojik dayanıklılık ve psikolojik iyi olma ilişkisinde iyimserliğin aracı rolü: Hastane çalışanları üzerine bir araştırma. İş ve insan Dergisi, 3(2), 119-127.

Karcıoğlu, F., Timuroğlu, K., \& Çınar, O. (2009). Örgütsel iletişim ve iş tatmini ilişkisi: Bir uygulama. İstanbul Üniversitesi işletme Iktisadi Enstitüsü Dergisi-Yönetim, 67, 59-76.

Keleş, H. N. (2017). Anlamlı iş ile psikolojik iyi oluş ilişkisi. The Journal of Happiness \& Well-Being, 5(1), $154-167$.

Kermen, U., Tosun, N. İ., \& Doğan, U. (2016). Yaşam doyumu ve psikolojik iyi oluşun yordayıcısı olarak sosyal kaygı. Eğitim Kuram ve Uygulama Araştırmaları Dergisi, 2(1), 20-29. 
Keyes, C. L. M., Shmotkin, D., \& Ryff, C. D. (2002). Optimizing well-being: The empirical encounter of two traditions. Journal of Personality and Social Psychology, 82(6), 1007-1022.

Limbert, C. (2004). Psychological well-being and job satisfaction amongst military personnel on unaccompanied tours: The impact of perceived social support and coping strategies. Military Psychology, 16(1), 37-51.

Luthans, F. (2011). Organizational behavior: An evidence-based approach. New York: The McGraw-Hill Companies.

Lyubomirsky, S., King, L., \& Diener E. (2005). The benefits of frequent positive affect: Does happiness lead to success? Psychological Bulletin, 131(6), 803-855.

Lyubomirsky, S., Tkach, C., \& DiMatteo, M. R. (2006). What are the differences between happiness and selfesteem. Social Indicators Research, 78(3), 363-404.

Lyubomirsky, S. (2007). The how of happiness. London: Sphere.

Mackinnon, D. P., Lockwood, C. M., \& Williams, J. (2004). Confidence limits for the indirect effect: Distribution of the product and resampling methods. Multivariate Behavioral Research, 39(1), 99-128.

Michalos, A. C., \& Orlando, J. A. (2006). Quality of life of some under-represented survey respondents: Youth, aboriginals and unemployed. Social Indicators Research, 79, 191-213.

Morris, M. L., Messal, C. B., \& Meriac, J. P. (2013). Core self-evaluation and goal orientation: Understanding work stress. Human Resource Development Quarterly, 24(1), 35-62.

Nunnally, J. C. (1978). Psychometric theory. New York: McGraw-Hill

Nübold, A., Muck, P. M., \& Maier, G. W. (2013). A new substitute for leadership? Followers' state core self-evaluations. The Leadership Quarterly, 24(2013), 29-44.

Oishi, S., Diener, E. F., Lucas, R. E., \& Suh, E. M. (1999). Cross-cultural variations in predictors of life satisfaction: Perspectives from needs and values. Personality and Social Psychology Bulletin, 25, 980-990.

Oruç, E. (2019). İş şekillendirmenin psikolojik iyi oluşa etkisinde işin anlamının aracılık etkisi. Sakarya Üniversitesi İşletme Enstitüsü Dergisi, 1(1), 24-28.

Özdemir, A.A. (2016). Çalışanların benlik yönelimlerinin liderlik ihtiyaçları ve psikolojik iyi oluş halleri üzerindeki rolü. Türk Psikoloji Yazıları, 19(38), 23-32.

Pannells, T. C., \& Claxton, A. F. (2008). Happiness, creative ideation, and locus of control. Creativity Research Journal, 20(1), 67-71.

Preacher, K. J., \& Kelley, K. (2011). Effect size measures for mediation models: Quantitative strategies for communicating Indirect effects. Psychological Methods, 16(2), 93-115.

Ramezani, S. G., \& Gholtash, A. (2015). The relationship between happiness, self-control and locus of control. International Journal of Educational and Psychological Researches, 1(2), 100-104.

Robbins, S. P., \& Judge, T. A. (2019). Örgütsel davranış. Çev. İ. Erdem, Organizational behaviour. Ankara: Nobel Akademik Yayıncılık.

Rucker, D. D., Preacher, K. J., Tormala, Z. L., \& Petty, R. E. (2011). Mediation analysis in social psychology: Current practices and new recommendations. Social and Personality Psychology Compass, 5(6), 359-371.

Rukh, G., Dang, J., Olivo, G., Ciuculete, D. M., Rask-Andersen, M., \& Schiöth, H. B. (2020). Personality, lifestyle and job satisfaction: Causal association between neuroticism and job satisfaction using Mendelian randomisation in the UK biobank cohort. Translational Psychiatry, 10(1), 1-9.

Ryff, C. D. (1989). Happiness is everything, or is it? Explorations on the meaning of psychological well-being. Journal of Personality and Social Psychology, 57(6), 1069-1081.

Ryff, C. D. (1995). Psychological weil-being in adult life. Current Directions in Psychological Science, 4(4), 99-104.

Saylan, T. (2008). Çalışanların iş tatminini etkileyen faktörlerin belirlenmesine yönelik bir alan araştırması. Gazi Üniversitesi Sosyal Bilimler Enstitüsü, Yayınlanmamış Yüksek Lisans Tezi, Ankara.

Schumacker, R. E., \& Lomax, R. G. (2010). A beginner's guide to structrual equation modeling (3rd Edition). New York: Routledge.

Schneider, T. R. (2004). The role of neuroticism on psychological and physiological stress responses. Journal of Experimental Social Psychology, 40(6),795-804.

Sevimli, H. (2015). Örgütsel bağlılık ile psikolojik iyilik hali arasındaki ilişkinin çeşitli değişkenler açısından incelenmesi. İstanbul Kültür Üniversitesi Sosyal Bilimler Enstitüsü, Yüksek Lisans Tezi, İstanbul. 
Shapiro, D. L. (2010). Relational identity theory: A systematic approach for transforming the emotional dimension of conflict. American Psychologist, 65(7), 634-645.

Tabachnick, B., \& Fidell, L. (2012). Using multivariate statistics. London: Pearson.

Tatlığlu, K. (2015). Üniversite öğrencilerinin aylık gelir ve harcama düzeyi ile psikolojik iyi oluşları arasındaki ilişkinin incelenmesi (Bingöl Üniversitesi örneği). Elektronik Sosyal Bilimler Dergisi, 14(55), 1-15.

Telef, B. B. (2013). Psikolojik iyi oluş ölçeği: Türkçeye uyarlama, geçerlik ve güvenirlik çalışması. Hacettepe Üniversitesi Eğitim Fakültesi Dergisi, 28(3), 374-384.

Telef, B. B., Uzman, E., \& Ergün, E. (2013). Öğretmen adaylarında psikolojik iyi oluş ve değerler arasındaki ilişkinin incelenmesi. Turkish Studies - International Periodical for the Languages, Literature and History of Turkish or Turkic, 8(12), 1297-1307.

Tekirgöl, Y. D. (2011). Çalışanlarda mesleki benlik saygısının iş tatmini ve yaşam mutluluğu ile ilişkisi. Maltepe Üniversitesi Sosyal Bilimler Enstitüsü, Yüksek Lisans Tezi, İstanbul.

Temel Eğinli, A. (2009). Çalışanlarda iş doyumu: Kamu ve özel sektör çalışanlarının iş doyumuna yönelik bir araştırma. Atatürk Üniversitesi Iktisadi ve Idari Bilimler Dergisi, 23(3), 35-52.

Türkoğlu, T., \& Yurdakul, Ü. (2017). Mobilya endüstrisinde çalışanların iş doyumu ile iş performansı arasındaki ilişkinin araştırılması. Artvin Çoruh Üniversitesi Orman Fakültesi Dergisi, 18(1), 88-97.

van Zyl, Y., \& Dhurup, M. (2018). Self-efficacy and its relationship with satisfaction with life and happiness among university students. Journal of Psychology in Africa, 28(5), 389-393.

Watson, D. (2000). Mood and temperament. New York: Guilford Press.

Wright, T. A., \& Bonett, D. G. (2007). Job satisfaction and psychological well-being as nonadditive predictors of workplace turnover. Journal of Management, 33(2), 141-160.

Wright, T. A., Cropanzano, R., \& Bonett, D. G. (2007). The moderating role of employee positive well being on the relation between job satisfaction and job performance. Journal of Occupational Health Psychology, 12(2), 93-104.

Wright, T. A., Cropanzano, R., Bonett, D. G., \& Diamond, W. J. (2009). Psychological well-being and work engagement among Italian social workers: Examining the mediational role of job resources. Journal of Organizational Behavior, 30(2), 193-208.

Yetim, Ü. (2001). Toplumdan bireye mutluluk resimleri. İstanbul: Bağlam Yayınları.

Yıldız Bağdoğan, S. (2018). Algılanan örgütsel destek, psikolojik iyi oluş ve işten ayrılma niyeti arasındaki ilişkilerin değerlendirilmesi. "iş, GüÇ" Endüstri iliş̧kileri ve Insan Kaynakları Dergisi, 20(3), 5-20.

Zhao, X., Lynch Jr, J. G., \& Chen, Q. (2010). Reconsidering Baron and Kenny: Myths and truths about mediation analysis. Journal of Consumer Research, 37(2), 197-206.

Zhang, J., Wu, Q., Miao, D., Yan, X., \& Peng, J. (2014). The impact of core self-evaluations on job satisfaction: The mediator role of career commitment. Social Indicators Research, 116(3), 809-822. 